\title{
Sodan ja turvallisuuden teknologiat Suomen historiassa
}

Sodankäyntiin on aina kuulunut monenlaista teknologiaa itse aseista ja linnoituksista joukkojensiirtovälineisiin ja huoltojärjestelmiin. Sodan muutos on sidoksissa teknologian kehitykseen, teollistumiseen ja yhteiskunnan teknologiaa koskeviin käsityksiin. Sodan koskettaessa koko yhteiskuntaa siviilien ja infrastruktuurin suojelu sekä yhteiskunnan toimintakyky näyttäytyvät tärkeinä turvallisuuskysymyksinä omine teknologisine ulottuvuuksineen. Silti kaikista uusista sotateknologioista ei tule ratkaisua koettuihin uhkakuviin eikä uusi teknologia noin vain korvaa jo käytössä olevaa. Kaikki hankinnat eivät myöskään onnistu, minkä takia improvisaatiolla ja niukkuuden hallinnalla on merkityksensä sotateknologioiden kehityksessä.

Yksityinen tai julkinen sotateollisuus on olennainen sodankäynnin edellytys. Sen ja sotavoimien välille muodostuu monenlaisia hallinnan ja vuorovaikutuksen sidoksia niin rauhan kuin sodan aikana. Teknologian ja tuotannon taustalla häämöttävät tiede ja tuotekehitys sitovat yliopistot, ajatushautomot ja laboratoriot osaksi sodan teknologisia verkostoja. Aseita, sotakoneita ja -järjestelmiä koskevien aikalaiskokemusten pelkistyminen arkkityyppisiksi kertomuksiksi tuottaa yhteisöllisesti jaettuja selviytymiskertomuksia traumaattisista kokemuksista hämärtäen näin sodan teknologisen muutoksen yhteiskunnallista vaikutusta.

Tässä teemanumerossa sodan ja turvallisuuden teknologiat nousevat osaksi Suomen tarinaa Ruotsin valtakunnan sotaisasta 1700-luvusta itsenäisen valtion 1900-luvun alkupuoliskon murroksiin. Kolme vertaisarvioitua artikkelia valottaa sodan teknologisen historian monia ulottuvuuksia ruokahuollosta naamiointiin ja tieteellisistä innovaatioista myyttisiin teknologiakäsityksiin. Numeron avaavassa artikkelissa Kuivatun viljan varastoinnin maa Helsingin yliopistossa väitöskirjaansa viimeistelevä Sampsa Hatakka valottaa Ruotsin valtion makasiinijärjestelmän merkitystä huoltovarmuudelle ja ruokahuollolle 1700-luvun puolivälissä. Toisessa pitkässä artikkelissa Hehkulampuilla vihollista vastaan tutkijatohtori Timo Vilén esittelee Alvar Wilskan suojavalaisujärjestelmän kehitystä ja testausta Vuoksenlaaksossa toisen maailmansodan aikana. Kolmannessa, englanninkielisessä artikkelissa The development of Finnish anti-tank weapons, 1918-1939 historiantutkija Michael Halila pureutuu panssarintorjuntateknologian hankinnan ongelmiin Suomen puolustusvoimissa itsenäisyyden ensimmäisten vuosikymmenten aikana. Yhdessä nämä tutkimukset nostavat esiin uusia, tärkeitä näkökulmia sodankäynnin historiasta.

Aiheen käsittelyä täydentää Suomen kansallismuseossa nykyisin työskentelevän päätoimittajan arvostelu Ruotsin sotamuseon, Armémuseumin näyttelyistä. Mukaan ehti myös Panu Nykäsen kirja-arvostelu Olavi Pihan mittavasta valimoteollisuuden historiasta Suomen valimoteollisuus.

Tekniikan Waiheita kamppailee edelleen omalla digitaalisella rintamallaan laadukkaan, suomenkielisen ja Suomea käsittelevän tekniikan historian puolesta. Vapaaehtoisvoimin tehty julkaisu tarvitsee jatkossakin harrastajien ja vapaaehtoisten pyyteetöntä tukea, Tekniikan Historian Seuran jäseninä, aktiivisina historian harrastajina, toimittajina sekä vertaisarvioijina ja tekniikan historian tutkijoina ja kirjoittajina. Vaikka tämä numero ilmestyykin edellisen tavoin myöhässä, ovat kuluvan vuoden loput numerot jo työn alla. Pahoittelen viivästystä ja toivotan mitä järisyttävimpiä lukuhetkiä!

\section{Aaro Sahari}

Päätoimittaja 